Article

\title{
Synthesis of a Functionalized Benzofuran as a Synthon for Salvianolic Acid C Analogues as Potential LDL Antioxidants
}

\section{Gabriela López-Frías, Alejandro A. Camacho-Dávila *, David Chávez-Flores, Gerardo Zaragoza-Galán and Víctor H. Ramos-Sánchez}

Facultad de Ciencias Químicas, Universidad Autónoma de Chihuahua, Circuito Universitario, Campus Universitario \#2, Apartado Postal 669, Chihuahua, Chih. 31125, Mexico;

E-Mails: gaby_ca23@hotmail.com (G.L.-F.); dchavezf@uach.mx (D.C.-F.); ger210582@yahoo.com.mx (G.Z.-G.); vramos@uach.mx (V.H.R.-S.)

* Author to whom correspondence should be addressed; E-Mail: acamach@uach.mx; Tel.: +52-61-423-6600 (ext. 4251); Fax: +52-61-423-6607.

Academic Editor: Derek J. McPhee

Received: 9 April 2015 / Accepted: 7 May 2015 / Published: 14 May 2015

\begin{abstract}
A palladium mediated synthesis of a common synthon for the syntheses of antioxidant analogues of naturally occurring salvianolic acids is presented. The synthetic route may be used to obtain analogues with a balanced lipophilicity/hydrophilicity which may result in potentially interesting LDL antioxidants for the prevention of cardiovascular diseases.
\end{abstract}

Keywords: benzofuran; antioxidant; palladium

\section{Introduction}

Oxidative damage of low density lipoprotein (LDL) plays a key role in the pathogenesis of several disorders, especially cardiovascular diseases (CVD), atherosclerosis and hypercholesterolemia among many others [1]. Oxidative stress may result in an impairment of glucose uptake in type 2 diabetes [2]. It is a fact that lipid oxidation is associated with platelet activation therefore resulting in an increase on the risk of CVD such as thrombosis and stroke [3].

In recent years, the intake of naturally occurring antioxidants has been associated with a benefit for the prevention of several conditions such as cancer, ageing, CVD and others [4,5]. These observations 
suggest that fruits and vegetables may have some protective effect against oxidative damage in the body [6-8]. However, as previously reported, the mechanisms of absorption, distribution and metabolism may have an effect on the effectiveness of these natural antioxidants [9-11].

For many years, traditional Chinese medicine has been using different extracts and concoctions of native plants for the treatment of different conditions [12,13]. Among these plants, the Chinese plant danshen (Salvia milthiorrhiza) and the Taiwanese plant Tournefortia sarmentosa Lam. have been used as detoxicants, anti-inflammatory and have also been used as an aid to promote blood circulation, and in the treatment of other causes such as stroke, atherosclerosis and thrombosis [14,15]. From the aqueous extracts of these plants several compounds have been isolated (Figure 1), including salvianolic acid C (1) and some novel compounds such as tournefolic acid A (2) and tournefolal (3) [16]. All of which possess in common a polyphenolic structure and a benzofuran ring system [17,18]. All of the isolated compounds showed an important effect in preventing $\mathrm{Cu}^{2+}$-induced LDL oxidation, indicating that these polyphenolic compounds could prevent LDL oxidation by the scavenging of free radicals [19].

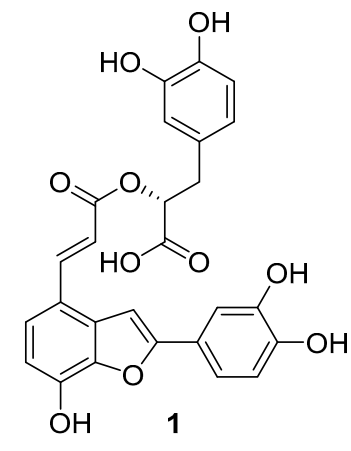

Salvianolic acid C

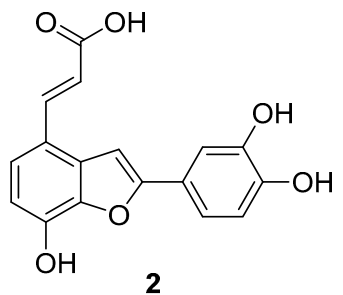

Tournefolic acid A

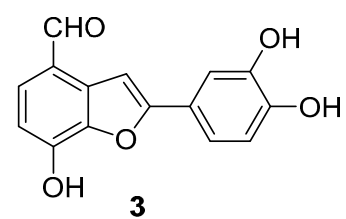

Tournefolal

Figure 1. Structures of natural benzofuran antioxidants isolated from Salvia species.

Some previous reports on pharmacokinetic studies have shown that water soluble compounds isolated from S. miltiorhiza possess strong antioxidant and lipid protective activities [20]. It is reported that salivianolic acids exert a protective effect by scavenging oxygen free radicals [20,21]. One of the problems associated with these compounds is their poor bio-availability due to their high hydrophilicity [22] resulting from the presence of the catechol moiety, and thus being metabolized to other mostly methylated analogues from which the biological activity is unknown [23]. Therefore, considering the important activity of these derivatives as potential therapeutical agents for the treatment of coronary and circulatory diseases, the development of novel analogues, possessing structures which can be modified through the attachment of different functionalities to modify their lipohilicity/hydrophilicity, is important in order to obtain analogues for biological assays [24,25].

One of the main factors for the antioxidant activity of these compounds is the presence of the catechol function. This is present in many naturally occurring antioxidant compounds such as flavonoids which are of great importance due to the health associated benefits obtained from their consumption [26-30]. However, bioavailability depends on a balance between lipophilicity and hydrophilicity, making this factor essential for the biological activity of this type of compounds [22,31]. Thus, finding a balance between these two factors could be a way to develop analogues with better absorption and improved 
biological activity [31,32]. Additionally, the benzofuran moiety is also present in biologically active natural products possessing antiviral, antitumor, antioxidant and antifungal activities, among others [33].

In connection with another project, we needed to synthesize some analogues of the reported tournefolic acid A $\mathbf{2}$ and tournefolal $\mathbf{3}$ containing a site where some other functionality could be installed to modify their lipophilic properties while maintaining a catechol structure intact. Hence, in this paper we present an approach to a functionalized benzofuran scaffold which can be further functionalized by the attachment of different functional groups while maintaining the catechol from which analogues of either salvianolic acid $\mathrm{C}$ or tournefolic acid A could be obtained in order to evaluate the potential biological activity of the obtained derivatives.

Previously, coumpounds 1-have been obtained using the tandem palladium-copper mediated cross-coupling/cyclization of 2-iodo-3-hydroxy-4-benzyloxybenzaldehyde $\mathbf{4}$ and the benzylic protected alkynyl catechol 5 followed by deprotection of benzofuran $\mathbf{6}$ by reductive elimination of the benzyl protecting groups to afford tournefolal (3) from which 1 and $\mathbf{2}$ were obtained as shown in Scheme 1 [34].

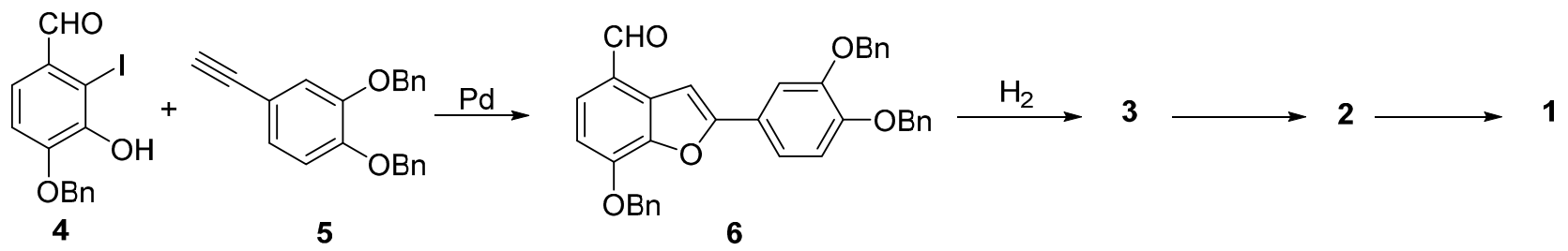

Scheme 1. Synthetic route to salvianolic acid derivatives.

In another report [25], the synthesis of a pentamethyltournefolic acid A $\mathbf{1 0}$ was obtained through the same reaction between a functionalized o-iodophenol $\mathbf{7}$ and a functionalized copper phenylacetylide 8 to yield the trimethoxytournefolal 9 from which 11 was obtained (Scheme 2). Further functionalization of pentamethyltournefolic acid A 10 furnished the pentamethylsalvianolic acid C 11. Attempts to remove the methyl groups by different strategies resulted in a complete failure to furnish any of the desired salvianolic acid $\mathrm{C}$. This result has been observed with similar substrates containing a benzofuran ring system [35].<smiles>O=Cc1ccc(O)c(O)c1O</smiles>

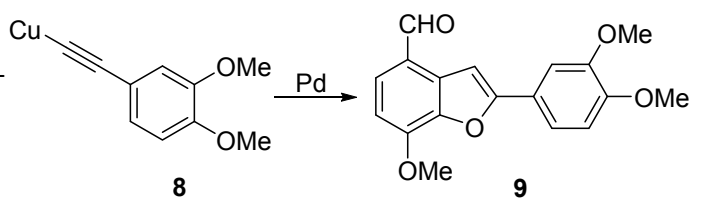<smiles>COc1ccc(-c2cc3c(OC)ccc(/C=C/C(=O)O)c3o2)cc1OC</smiles><smiles>COc1ccc(CC(=O)OC(=O)C=Cc2ccc(OC)c3c2C=C(O)C3=O)cc1OC</smiles>

Scheme 2. Synthetic route to pentamethylsalvianolic acid C 11. 
As we were interested in the synthesis of analogues of salvianiolic acid C (1), tournefolic acid A (2) and tournefolal (3) from a common intermediate, which could be functionalized at the phenolic position para to the cinnamic acid chain of $\mathbf{2}$ in order to modify the lipophilicity, while maintaining the catechol structure in ring $\mathrm{C}$, we were faced with the problem of finding a properly functionalized derivative which could be easily deprotected under mild conditions and without disturbing any other functionality installed in the molecule in order to access all required derivatives from a single common intermediate.

Initially, we considered the use of the palladium-mediated coupling between $o$-halophenols and alkynes in a similar way as the previously descried synthesis of $\mathbf{1}$ and $\mathbf{2}$ [35]. This methodology has been used successfully in the synthesis of diversely functionalized benzofurans [36,37]. Hence, palladium-mediated cross coupling between ethynylcatechol 13 with o-haloaldehyde 12 (Scheme 3) could furnish the corresponding protected tournefolal ketal $\mathbf{1 4}$ which is a scaffold ready to attach further functionalities into the free phenolic group by alkylation of the phenol group of $\mathbf{1 4}$ with different alkyl halides to produce functionalized tournefolal ketal 15.<smiles>O=Cc1ccc(O)c(O)c1I</smiles>

12<smiles>C#Cc1ccc2c(c1)OC(C)(C)O2</smiles>

13<smiles>CCC1(C)Oc2ccc(-c3cc4c(C=O)ccc(O)c4o3)cc2O1</smiles>

14<smiles>[R17]c1ccc(C=O)c2cc(-c3ccc4c(c3)OC(C)(C)O4)oc12</smiles>

R1= Alkyl group

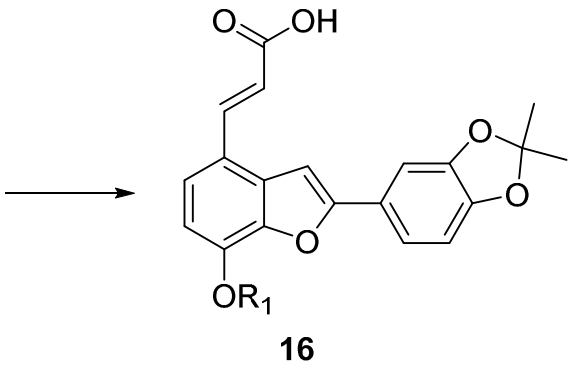

16
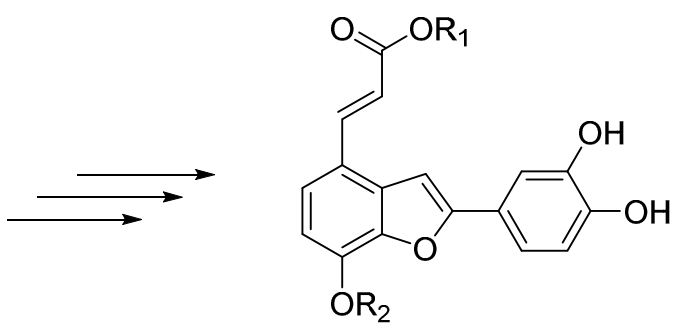

17a R10 H, R2= alkyl groups 17b R1= alkyl R2= alkyl

Scheme 3. Proposed synthetic route to salvianolic acid analogues.

Attachment of the propenoic acid chain to aldehyde 15 will produce alkylated tournefolic acid A ketal 16, which can be further manipulated at the carboxyl function to install the required functionality to produce analogues $\mathbf{1 7}$ of either $\mathbf{1}$ or $\mathbf{2}$. This way, several analogues of tournefolic acid A or salvianolic acid $\mathrm{C}$ can be obtained to be evaluated for their biological activity. In this paper we report the progress made in this approach.

\section{Results and Discussion}

As a starting material and as a source of ring $\mathrm{C}$ of the benzofuran scaffold, we selected the inexpensive and readily available catechol (17) and isovanillin (22) as the source of A ring. Initially (Scheme 4), protection of the phenolic groups in catechol 17 was achieved by reaction between 17 and acetone in the presence of phosphorus trichloride to afford the cyclic ketal 18 in 85\% yield [38]. With ketal 18 readily available, halogenation with NBS in DMF afforded the corresponding bromide 19 in $80 \%$ yield $[39,40]$. 
Sonogashira coupling of $\mathbf{1 9}$ with trimethylsilylacetylene resulted in a poor yield of the coupling product 21 attributed tothe electron richness of the ring [41]. Consequently, the change of bromine for iodine was required in order to improve the yield in this step. Reaction of ketal $\mathbf{1 8}$ with iodine in ethanol in the presence of silver sulfate afforded the corresponding iodo compound 21 in $92 \%$ yield [42]. Sonogashira coupling of 21 with TMS-acetylene [43] and removal of silicon under standard conditions $\left(\mathrm{K}_{2} \mathrm{CO}_{3} /\right.$ methanol) furnished the desired alkyne $\mathbf{1 3}$ in $89 \%$ yield.

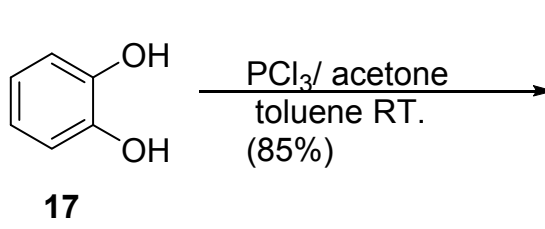

17
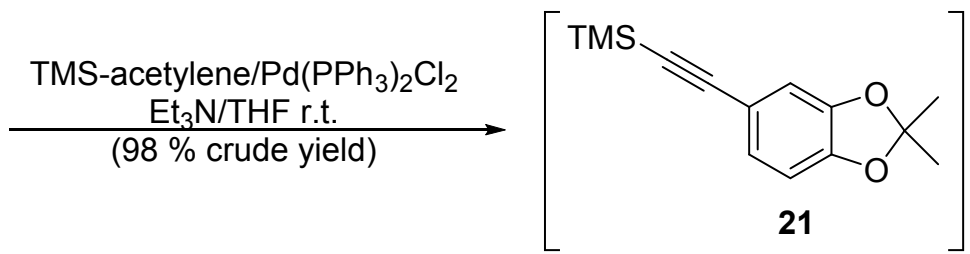

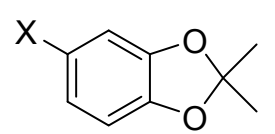

$19 \mathrm{X}=\mathrm{Br}$ $20 X=1$

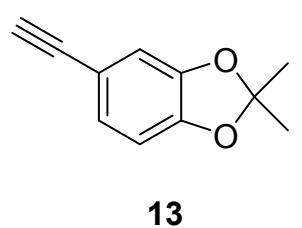

Scheme 4. Synthetic route to alkyne precursor 13.

The fragment $\mathbf{1 2}$ corresponding to ring A was obtained starting from isovanillin 22 as previously reported [44]. Compound 12 was obtained in 65\% overall yield (Scheme 5).<smiles>COc1ccc(C=O)cc1O</smiles>

22<smiles>COc1ccc(C=O)c(I)c1O</smiles>

7

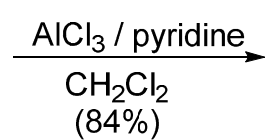

$(84 \%)$<smiles>O=Cc1ccc(O)c(O)c1I</smiles>

12

Scheme 5. Synthetic route to iodophenol precursor 12.

Having obtained the necessary precursors, the coupling-cyclization reaction was performed (Scheme 6). Thus, treatment of a solution of iodide 12 in DMF with alkyne 13 in the presence of copper (I) iodide (4 mol \%), $\mathrm{Pd}\left(\mathrm{PPh}_{3}\right)_{2} \mathrm{Cl}_{2}(2 \mathrm{~mol} \%)$ and triethylamine (3 equivalents) at $65-70{ }^{\circ} \mathrm{C}$ for $12 \mathrm{~h}$ afforded a mixture of products from which the desired tournefolal ketal 14 was detected in the crude reaction TLC by their intense blue fluorescence under short UV-light. Purification of the reaction mixture by flash column chromatography resulted in the isolation of pure tournefolal ketal 14 in $64 \%$ yield. No attempts to optimize this reaction by changing the catalyst or their ratio were performed. 


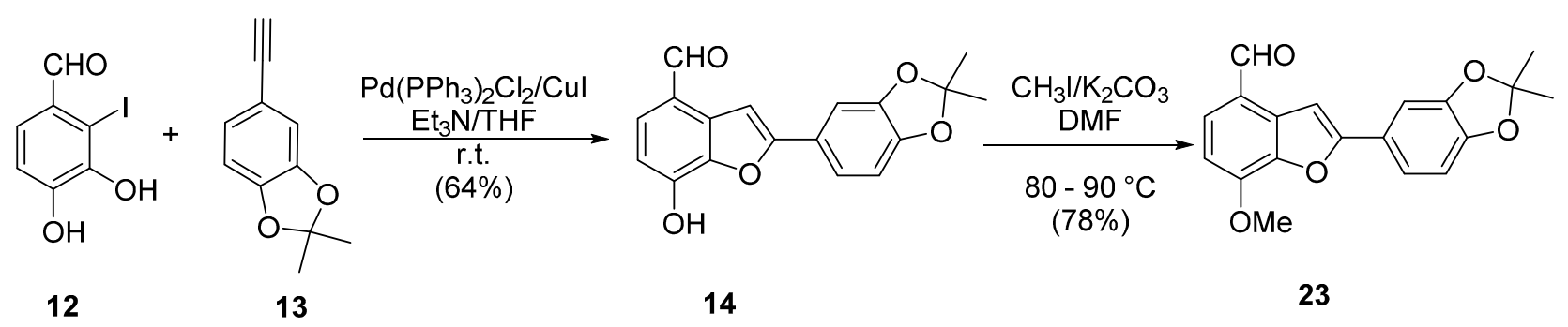

Scheme 6. Scheme for Pd-catalyzed coupling reaction to benzofuran ring system.

To evaluate the reactivity of the phenol group with alkylating agents, the reaction of $\mathbf{1 4}$ with iodomethane in potassium carbonate to afford the methoxybenzofuran aldehyde $\mathbf{2 3}$ was performed, resulting in a $78 \%$ yield, thus demonstrating that this position can be readily functionalized. Deprotection of 14 by stirring with neat trifluoroacetic acid at room temperature afforded after purification the previously reported tournefolal (3) in $70 \%$ yield.

Formation of the propenoic acid chain was accomplished by reaction of protected hydroxytournefolal $\mathbf{1 4}$ or methoxytournefolal $\mathbf{2 3}$ with excess of malonic acid in pyridine containing a catalytic amount of piperidine at room temperature, thus affording the protected acids $\mathbf{1 6}$ and $\mathbf{2 4}$ in good yields (Scheme 7). Acid 16 is a convenient starting material for the syntheses of either derivatives of salvianolic acid $\mathrm{C}$ or tournefolic acid A which can be functionalized at the free phenolic position.
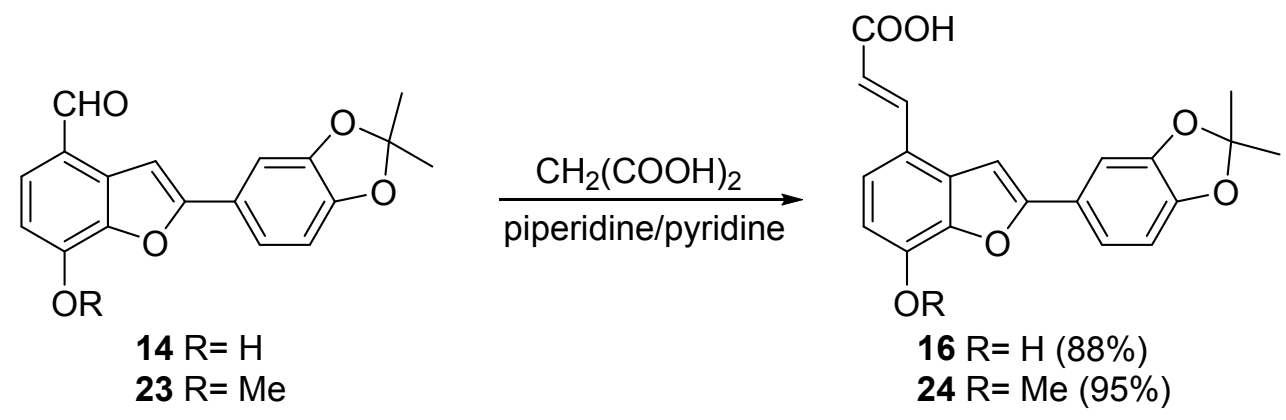

Scheme 7. Functionalization route to salvianolic acid $\mathrm{C}$ synthon.

\section{Experimental Section}

\subsection{General Methods}

Anhydrous THF was distilled over sodium benzophenone ketyl under $\mathrm{N}_{2}$; all other solvents and reagents were used from commercial sources without further purification. The silica gel (230-400 mesh, NATLAND, Durham, NC, USA) was used for column chromatography. ${ }^{1} \mathrm{H}-\mathrm{NMR}$ spectra were recorded at $500 \mathrm{MHz}$ and ${ }^{13} \mathrm{C}$-NMR spectra were recorded at $125 \mathrm{MHz}$ on a Varian V NMR System instrument (Varian Instruments, Palo Alto, CA, USA) Chemical shifts $(\delta)$ are given in ppm with reference to either to TMS (0.00) or the corresponding solvent signals [ ${ }^{1} \mathrm{H}-\mathrm{NMR}: \mathrm{CDCl}_{3}$ (7.27), $\mathrm{CD}_{3} \mathrm{SOCD}_{3}$ (2.5). ${ }^{13} \mathrm{C}-\mathrm{NMR}: \mathrm{CDCl}_{3}$ (77.0), $\mathrm{CD}_{3} \mathrm{SOCD}_{3}$ (39.52); $\mathrm{CD}_{3} \mathrm{COCH}_{3}$ (29.84). HRMS was recorded on a GC-Mate II GC-MS (Jeol, Tokyo, Japan). Low resolution MS was obtained on a Turbo Mass Gold mass spectrometer (Perkin-Elmer, Waltham, MA, USA). 


\subsection{Synthesis}

5-Iodo-2,2-dimethylbenzo[d][1,3]dioxole (20). 2,2-Dimethylbenzo[d][1,3]dioxole [38] (18, $10 \mathrm{~g}$, $66.58 \mathrm{mmol}), \mathrm{Ag}_{2} \mathrm{SO}_{4}(20.75 \mathrm{~g}, 66.58 \mathrm{mmol})$ and $\mathrm{I}_{2}(16.91 \mathrm{~g}, 66.58 \mathrm{mmol})$ were stirred for $2 \mathrm{~h}$ in anhydrous ethanol $(250 \mathrm{~mL})$ at room temperature. After this time, the iodine color disappeared completely and the mixture was filtered to eliminate the precipitated salt. Ethanol was removed on a rotary evaporator and the residue was then dissolved in $\mathrm{CH}_{2} \mathrm{Cl}_{2}(100 \mathrm{~mL})$ and the organic phase was washed with a $20 \% \mathrm{Na}_{2} \mathrm{~S}_{2} \mathrm{O}_{3}$ solution. The organic phase was separated, dried over $\mathrm{Na}_{2} \mathrm{SO}_{4}$, filtered and concentrated under reduced pressure to yield the practically pure iodoketal $\mathbf{2 0}$ as a yellow oil (16.91 g, $92 \%)$. This was used in the next step without further purification. ${ }^{1} \mathrm{H}-\mathrm{NMR}\left(\mathrm{CDCl}_{3}\right) \delta: 7.08(\mathrm{dd}, J=8.1$, $1.8 \mathrm{~Hz}, 1 \mathrm{H}) ; 7.02(\mathrm{~d}, J=1.8 \mathrm{~Hz}, 1 \mathrm{H}) ; 6.50(\mathrm{~d}, J=8.1 \mathrm{~Hz}, 1 \mathrm{H}) ; 1.65(\mathrm{~s}, 6 \mathrm{H}) .{ }^{13} \mathrm{C}-\mathrm{NMR}\left(\mathrm{CDCl}_{3}\right) \delta: 148.56$, 147.63, 130.00, 118.80, 117.48, 110.41, 81.63, 25.93. MS (CI): $m / z 276$ (M+, 100\%), 261, 149. 93, 63.

((2,2-Dimethylbenzo[d][1,3]dioxol-5-yl)ethynyl)trimethylsilane (21). Into a $100 \mathrm{~mL}$ r.b. flask equipped with a magnetic stirring bar were placed iodoketal 20 (9.63 g, $34.88 \mathrm{mmol}), \mathrm{CuI}(132 \mathrm{mg}, 2.0 \mathrm{~mol} \%)$ and $\mathrm{Pd}\left(\mathrm{PPh}_{3}\right)_{2} \mathrm{Cl}_{2}(979 \mathrm{mg}, 4 \mathrm{~mol} \%)$. The flask was stoppered with a septum and purged with Ar. Distilled THF $(50 \mathrm{~mL}), \mathrm{Et}_{3} \mathrm{~N}(14 \mathrm{~mL}, 100 \mathrm{mmol})$ were successively added trough a syringe and the mixture was stirred for $15 \mathrm{~min}$. After this time, ethynyltrimethylsilane ( $7.39 \mathrm{~mL}, 52 \mathrm{mmol}, 1.5$ equiv) was slowly added through a syringe, after a few minutes the mixture spontaneously warmed and the addition was continued maintaining the temperature below $35^{\circ} \mathrm{C}$. After the addition, the mixture was stirred $4 \mathrm{~h}$ and then diluted with ethyl acetate $(100 \mathrm{~mL})$. The mixture was filtered through Celite containing a layer of activated charcoal. The filtrate was concentrated under reduced pressure yielding a dark brown syrup. This was used in the next step without further purification. (Crude yield: $8.25 \mathrm{~g}$, 96\%). ${ }^{1} \mathrm{H}-\mathrm{NMR}\left(\mathrm{CDCl}_{3}\right): \delta 6.96(\mathrm{dd}, J=8.0,1.6 \mathrm{~Hz}, 1 \mathrm{H}) ; 6.82(\mathrm{~d}, J=1.6 \mathrm{~Hz}, 1 \mathrm{H}) ; 6.64(\mathrm{~d}, J=8.0 \mathrm{~Hz}$, $1 \mathrm{H}) ; 1.66(\mathrm{~s}, 6 \mathrm{H}) ; 0.22$ (s, 9H). MS (CI): $m / z 246(\mathrm{M}+), 232,191,108(100 \%), 43$.

5-Ethynyl-2,2-dimethylbenzo[d][1,3]dioxole (13). To a stirred solution of TMS alkynylketal $215 \mathrm{~g}$ (20.3 mmol) in anhydrous methanol $(50 \mathrm{~mL})$, solid $\mathrm{K}_{2} \mathrm{CO}_{3}(5.52 \mathrm{~g}, 40 \mathrm{mmol})$ was added and the mixture was vigorously stirred during $4 \mathrm{~h}$. After this time, the mixture was filtered over Celite and the Celite washed with methanol $(20 \mathrm{~mL})$. Removal of methanol under vacuum yielded a brown oil which was purified by column chromatography eluting with hexane/EtOAc $(9 / 1)$ to yield the pure alkyne ketal 13 (3.15 g, 89\%). ${ }^{1} \mathrm{H}-\mathrm{NMR}\left(\mathrm{CDCl}_{3}\right): \delta 6.99(\mathrm{dd}, J=8.0,1.6 \mathrm{~Hz}, 1 \mathrm{H}) ; 6.86(\mathrm{~d}, J=1.6 \mathrm{~Hz}, 1 \mathrm{H}) ; 6.67$ (dd, $J=8.0,0.5 \mathrm{~Hz}, 1 \mathrm{H}) ; 2.97(\mathrm{~s}, 1 \mathrm{H}) ; 1.67(\mathrm{~s}, 6 \mathrm{H}) .{ }^{13} \mathrm{C}-\mathrm{NMR}\left(\mathrm{CDCl}_{3}\right): \delta 148.20,147.23,126.42,118.7$, 114.63, 111.91, 108.34, 89.83, 75.41, 25.89). MS (CI): $m / z 174$ (M+), 159 (100\%), 135, 88 62, 50, 43. HRMS: Calculated for $\mathrm{C}_{11} \mathrm{H}_{10} \mathrm{O}_{2}: 174.0681$, found: 174.0681 .

2-(2,2-Dimethylbenzo[d] [1,3]dioxol-5-yl)-7-hydroxybenzofuran-4-carbaldehyde (14). To a two necked $100 \mathrm{~mL}$ r.b. flask equipped with a magnetic stirring bar was added successively $210 \mathrm{mg} \mathrm{Pd}\left(\mathrm{PPh}_{3}\right)_{2} \mathrm{Cl}_{2}$ (210 mg, $3 \mathrm{~mol} \%$ ), CuI $76 \mathrm{mg}$ (4 mol \%), of 3,4-dihydroxy-2-iodobenzaldehyde [44] (12, $2.6 \mathrm{~g} 10 \mathrm{mmol})$ and DMF $(35 \mathrm{~mL})$. After this, the flask was purged several times with argon and triethylamine $(5 \mathrm{~mL})$ was added via syringe. The mixture was heated in an oil bath at $80-90{ }^{\circ} \mathrm{C}$ and then a solution of alkyne 13 (1.456 g $8.36 \mathrm{mmol}, 1.2$ equiv) in DMF ( $8 \mathrm{~mL}$ ) was added via syringe during $30 \mathrm{~min}$ and after this, heating was continued for $20 \mathrm{~h}$. TLC $\left(\mathrm{SiO}_{2}\right.$, hexane/EtOAC 7/3) showed the presence of furan 14 as an 
intense blue fluorescence under short wave UV light. After the heating period, the volatiles were removed under reduced pressure and the residue adsorbed into silica gel which was directly applied to the chromatographic column packed with silica gel. Elution with hexane/EtOAc in a gradient $(7 / 3,6 / 4$, 5/5) afforded pure benzofuran 14 as a dark brown powder $(1.98 \mathrm{~g}, 64 \%) .{ }^{1} \mathrm{H}-\mathrm{NMR}\left(\mathrm{CDCl}_{3}\right): \delta 10.03$ (s, $1 \mathrm{H}) ; 7.63(\mathrm{~s}, 1 \mathrm{H}) ; 7.61(\mathrm{~d}, J=8.2 \mathrm{~Hz}, 1 \mathrm{H}) ; 7.40(\mathrm{dd}, J=8.1,1.7 \mathrm{~Hz}, 1 \mathrm{H}) ; 7.25(\mathrm{~d}, J=1.8 \mathrm{~Hz}, 1 \mathrm{H}) ; 6.91$ $(\mathrm{d}, J=8.1 \mathrm{~Hz}, 1 \mathrm{H}) ; 6.79(\mathrm{~d}, J=8.1 \mathrm{~Hz}, 1 \mathrm{H}) ; 1.71(\mathrm{~s}, 6 \mathrm{H}) .{ }^{13} \mathrm{C}-\mathrm{NMR}\left(\mathrm{CD}_{3} \mathrm{SOCD}_{3}\right) \delta: 190.91,159.52$, $148.77,148.10,145.85,139.22,131.99,130.57,123.11,122.56,119.45,118.84,110.31,108.62$, 105.60, 101.02, 25.87. HRMS Calculated for $\mathrm{C}_{18} \mathrm{H}_{14} \mathrm{O}_{5}: 310.0841$, found: 310.0840 .

2-(3,4-Dihydroxyphenyl)-7-hydroxybenzofuran-4-carbaldehyde (Tournefolal) 3. Benzofuran aldehyde 14 (100 mg, $0.322 \mathrm{mmol}$ ) was added to a cooled solution of neat trifluoroacetic acid $(2 \mathrm{~mL})$. The mixture was stirred at room temperature during $16 \mathrm{~h}$. The trifluoroacetic acid was removed in vacuo and the residue was purified by column chromatography on Sephadex LH20 eluting with methanol. Compound 3 was obtained as a greenish powder $(61 \mathrm{mg}, 70 \%)$. The spectral data agreed with the reported values [19,34]. ${ }^{1} \mathrm{H}-\mathrm{NMR}\left(\mathrm{CD}_{3} \mathrm{SOCD}_{3}\right): \delta 9.98(\mathrm{~s}, 1 \mathrm{H}) ; 7.67(\mathrm{~d}, J=8.2 \mathrm{~Hz}, 1 \mathrm{H}), 7.55(\mathrm{~s}, 1 \mathrm{H}) ; 7.34(\mathrm{~d}$, $J=2.1 \mathrm{~Hz}, 1 \mathrm{H}) ; 7.30(\mathrm{dd}, J=8.2,2.1 \mathrm{~Hz}, 1 \mathrm{H}) ; 6.88(\mathrm{~d}, J=9 \mathrm{~Hz}, 1 \mathrm{H}) ; 6.86(\mathrm{~d}, J=8.2 \mathrm{~Hz}, 1 \mathrm{H})$. ${ }^{13} \mathrm{C}\left(\mathrm{CD}_{3} \mathrm{SOCH}_{3}\right): \delta 190.42,158.83,147.91,147.26,145.72,142.49,131.58,130.37,120.77,120.58$, $117.27,116.21,112.38,110.20,99.16$.

(E)-3-(2-(2,2-dimethylbenzo[d] [1,3]dioxol-5-yl)-7-hydroxybenzofuran-4-yl)acrylic acid (16). Benzofuran aldehyde 14 (310 mg, $1 \mathrm{mmol})$ was dissolved in pyridine $(5 \mathrm{~mL})$ and then malonic acid $(1 \mathrm{~g}, 9.56 \mathrm{mmol})$ and a drop of piperidine was added. The mixture was stirred at room temperature during 5 days and then heated in an oil bath at $85-90{ }^{\circ} \mathrm{C}$ for $1 \mathrm{~h}$. The volatiles were removed under reduced pressure and the dark brown residue was purified by column chromatography eluting with a gradient of hexane/acetone $(7 / 3,6 / 4,5: 5)$ to afford acid 16 as a golden solid strongly fluorescent under short wave UV light (150 mg, 88\%). ${ }^{1} \mathrm{H}-\mathrm{NMR}\left(\mathrm{CDCl}_{3}\right): \delta 7.92(\mathrm{~d}, J=16.1 \mathrm{~Hz}, 1 \mathrm{H}) ; 7.63(\mathrm{~s}, 1 \mathrm{H}) ; 7.57(\mathrm{dd}, J=8.1,1.8 \mathrm{~Hz}$, $1 \mathrm{H}) ; 7.50(\mathrm{~d}, J=1.7 \mathrm{~Hz}, 1 \mathrm{H}) ; 7.47(\mathrm{dd}, J=8.3,0.6 \mathrm{~Hz}, 1 \mathrm{H}) ; 6.91(\mathrm{dd}, J=8.2,0.4 \mathrm{~Hz}, 1 \mathrm{H}) ; 6.86(\mathrm{~d}$, $\left.J=8.3 \mathrm{~Hz}, 1 \mathrm{H}) ; 6.52(\mathrm{~d}, J=16.0 \mathrm{~Hz}, 1 \mathrm{H}) ; 1.71(\mathrm{~s}, 6 \mathrm{H}) .{ }^{13} \mathrm{C} \mathrm{CD}_{3} \mathrm{COCD}_{3}\right) 168.30,158.11,149.34,149.03$, 145.01, 143.48, 131.79, 126.21, 124.59, 119.90, 119.81, 119.63, 116.41, 111.87, 109.37, 106.15, 100.33, 25.89 HRMS: Calculated for $\mathrm{C}_{20} \mathrm{H}_{16} \mathrm{O}_{6}: 352.0947$, found: 352.0934 .

2-(2,2-Dimethylbenzo[d] [1,3]dioxol-5-yl)-7-methoxybenzofuran-4-carbaldehyde (23). To a solution of aldehyde 14 (750 mg, $2.41 \mathrm{mmol}$ ) in DMF (5 mL) finely powdered $\mathrm{K}_{2} \mathrm{CO}_{3}(750 \mathrm{mg}, 5.42 \mathrm{mmol})$ was added. The mixture was stirred and to this, iodomethane $(0.5 \mathrm{~mL}, 8.03 \mathrm{mmol})$ was added in one portion. The mixture was heated in an oil bath at $70-80{ }^{\circ} \mathrm{C}$ for $24 \mathrm{~h}$. The reaction mixture was cooled and diluted with chloroform $(50 \mathrm{~mL})$. The mixture was diluted with water and the phases separated. The organic phase was washed with water $(6 \times 25 \mathrm{~mL})$ and dried over $\mathrm{Na}_{2} \mathrm{SO}_{4}$. Solvent removal at reduced pressure and column chromatography $\left(\mathrm{SiO}_{2}\right)$ of the residue eluting with hexane/ethyl acetate $4 / 1$ afforded pure 23 as a dark yellow solid (610 mg, 78\%). ${ }^{1} \mathrm{H}-\mathrm{NMR}\left(\mathrm{CDCl}_{3}\right): \delta 10.04(\mathrm{~s}, 1 \mathrm{H}) ; 7.64(\mathrm{~d}, J=8.3 \mathrm{~Hz}, 1 \mathrm{H})$; 7.62 (s, 1H); 7.44 (dd, $J=8.1,1.8 \mathrm{~Hz}, 1 \mathrm{H}) ; 7.29$ (d, $J=1.7 \mathrm{~Hz}, 1 \mathrm{H}) ; 6.86(\mathrm{~d}, J=8.3 \mathrm{~Hz}, 1 \mathrm{H}) ; 6.80$ (d, $J=8.1 \mathrm{~Hz}, 1 \mathrm{H}) ; 4.13(\mathrm{~s}, 3 \mathrm{H}) ; 1.71(\mathrm{~s}, 6 \mathrm{H}) .{ }^{13} \mathrm{C}-\mathrm{NMR}\left(\mathrm{CDCl}_{3}\right): \delta 190.74,159.28,149.59,148.62,148.04$, 
143.71, 131.0, 130.33, 123.3, 122.72, 119.45, 118.7, 108.55, 105.84, 105.68, 100.48, 56.44, 25.88. HRMS: Calculated for $\mathrm{C}_{19} \mathrm{H}_{16} \mathrm{O}_{5}: 324.0998$, found: 324.0993.

(E)-3-(2-(2,2-dimethylbenzo[d][1,3]dioxol-5-yl)-7-methoxybenzofuran-4-yl)acrylic acid Aldehyde 23 (500 mg, $1.54 \mathrm{mmol})$ was dissolved in pyridine $(5 \mathrm{~mL})$ and then malonic acid $(1 \mathrm{~g}$, $9.56 \mathrm{mmol})$ and a drop of piperidine was added. The mixture was heated in an oil bath at $85-90{ }^{\circ} \mathrm{C}$ for $4 \mathrm{~h}$. The mixture was poured into a mixture of ice $(50 \mathrm{~g})$ containing concentrated $\mathrm{HCl}(5 \mathrm{~mL})$. The precipitated yellow solid was recovered by filtration and washed with water several times. The acid was dried at $50{ }^{\circ} \mathrm{C}$ in vacuum and then washed with dichloromethane. This way, pure 24 was obtained as a yellow solid (536 mg, 95\%). ${ }^{1} \mathrm{H}-\mathrm{NMR}\left(\mathrm{CDCl}_{3}\right): \delta 7.82(\mathrm{~d}, J=16.1 \mathrm{~Hz}, 1 \mathrm{H}) ; 7.74(\mathrm{~s}, 1 \mathrm{H}) ; 7.56(\mathrm{~d}$, $J=8.4 \mathrm{~Hz}, 1 \mathrm{H}) ; 7.50(\mathrm{~d}, J=1.8 \mathrm{~Hz}, 1 \mathrm{H}) ; 7.48(\mathrm{dd}, J=8.1,1.8 \mathrm{~Hz}, 1 \mathrm{H}) ; 6.98(\mathrm{~d}, J=4.9 \mathrm{~Hz}, 1 \mathrm{H}) ; 6.96$ $(\mathrm{d}, J=4.5 \mathrm{~Hz}, 1 \mathrm{H}) ; 6.56(\mathrm{~d}, J=16.1 \mathrm{~Hz}, 1 \mathrm{H}) ; 4.02(\mathrm{~s}, 3 \mathrm{H}) ; 1.69(\mathrm{~s}, 6 \mathrm{H}) .{ }^{13} \mathrm{C}-\mathrm{NMR}\left(\mathrm{CD}_{3} \mathrm{SOCD}_{3}\right): \delta$ 167.99, 156.62, 147.86, 147.6, 146.18, 142.81, 141.56, 129.33, 125.43, 123.07, 119.52, 118.84, 118.82, 117.37, 108.65, 107.29, 105.25, 99.97, 56.10, 25.54. HRMS: Calculated for $\mathrm{C}_{21} \mathrm{H}_{18} \mathrm{O}_{6}$ : 366.1103, found: 366.1110 .

\section{Conclusions}

In summary, the synthesis of the natural benzofuran tournefolal (3) and its ketal protected derivative $\mathbf{1 4}$, as well as ketal protected tornefolic acid A $\mathbf{1 6}$ have been synthesized to provide a convenient access to precursors of analogues of either salvianolic acid C (1) or tournefolic acid A (2). Further functionalization of aldehyde $\mathbf{1 4}$ with different alkylating agents could be realized in a straightforward manner as demonstrated by methylation with iodomethane to access diverse analogues to evaluate the effect of these chains in their biological action. Also, the aldehyde function can be transformed into other functionalities, thus increasing range of analogue syntheses. Synthetic studies of different alkylated derivatives and biological evaluation of these compounds are currently underway and will be reported in due course.

\section{Supplementary Materials}

Supplementary materials can be accessed at: http://www.mdpi.com/1420-3049/20/05/8654/s1.

\section{Acknowledgments}

The authors gratefully acknowledge the support given by Escuela Nacional de Ciencias Biológicas of the Instituto Politécnico Nacional (México) through Joaquín Tamaríz for the recording of the NMR and HRMS spectra of synthesized compounds. We also acknowledge financial support of Dirección de Investigación y Posgrado of FCQ-UACH.

\section{Author Contributions}

A.C.D. and G.Z.G. conceived and designed the experiments. G.L.F. and A.C.D. performed the experiments. D.C.F. and V.H.R.S. analyzed the NMR data. A.C.D., G.Z.G. and V.H.R.S. wrote the paper. All authors read and approved the final manuscript. Part of this work constitutes the B. Sc. Thesis of G.L.F. 


\section{Conflicts of Interest}

The authors declare no conflict of interest.

\section{References}

1. Li, H.; Horke, S.; Förstermann, U. Oxidative stress in vascular disease and its pharmacological prevention. Trends Pharmacol. Sci. 2013, 34, 313-319.

2. Pop-Busui, R.; Mehta, M.; Pennathur, S. Oxidative Stress and Cardiovascular Disease in Diabetes. In Studies in Diabetes. Oxidative Stress in Applied Basic Research and Clinical Practice; Obrosova, I., Stevens, M.J., Yorek, M.A., Eds.; Springer: New York, NY, USA, 2014; pp. 189-235.

3. Dokken, B.B. The Pathophysiology of Cardiovascular Disease and Diabetes: Beyond Blood Pressure and Lipids. Diabetes Spectrum. 2008, 21, 160-165.

4. Garrett, A.R.; Gupta-Elera, G.; Keller, M.A.; O’Neill, K.L. Bioactive Foods in Aging: The Role in Cancer Prevention and Treatment. In Bioactive Food as Dietary Interventions for the Aging Population; Watson, R.R., Preedy, V.R., Eds.; Academic Press: San Diego, CA, USA, 2013; pp. 33-45.

5. Zamora, R.; Delgado, R.M.; Hidalgo, F.J. Effects of Oxidation on the Nutritive and Health-Promoting Value of Food Components. In Food Oxidants and Antioxidants: Chemical, Biological, and Functional Properties; CRC Press: Boca Raton, FL, USA, 2013; pp. 197-234.

6. González-Vallinas, M.; González-Castejón, M.; Rodríguez-Casado, A.; Ramírez de Molina, A. Dietary phytochemicals in cancer prevention and therapy: A complementary approach with promising perspectives. Nutr. Rev. 2013, 71, 585-599.

7. Rubió, L.; Motilva, M.J.; Romero, M.P. Recent Advances in Biologically Active Compounds in Herbs and Spices: A Review of the Most Effective Antioxidant and Anti-Inflammatory Active Principles. Crit. Rev. Food Sci. Nutr. 2013, 53, 943-953.

8. Martin, C.; Zhang, Y.; Tonelli, C.; Petroni, K. Plants, Diet, and Health. Annu. Rev. Plant Biol. 2013, 64, 19-46.

9. Murphy, M.P. Antioxidants as therapies: can we improve on nature? Free Radic. Biol. Med. 2014, $66,20-23$.

10. Hao, H.; Zheng, X.; Wang, G. Insights into drug discovery from natural medicines using reverse pharmacokinetics. Trends Pharmacol. Sci. 2014, 35, 168-177.

11. Velderrain-Rodríguez, G.R.; Palafox-Carlos, H.; Wall-Medrano, A.; Ayala-Zavala, J.F.; Chen, C.Y.O.; Robles-Sánchez, M.; Astiazaran-García, H.; Alvarez-Parrillab, E.; González-Aguilar, G.A. Phenolic compounds: Their journey after intake. Food Funct. 2014, 5, 189-197.

12. Ding, W.X.; Gu, J.Y.; Cao, L.; Li, N.; Ding, G.; Wang, Z.; Chen, L.; Xu, X.J.; Xiao, W. Traditional Chinese herbs as chemical resource library for drug discovery of anti-infective and anti-inflammatory. J. Ethnopharm. 2014, 155, 589-598.

13. Sucher, N.J. The application of Chinese medicine to novel drug discovery. Expert Opin. Drug Discov. 2013, 8, 21-34.

14. Lu, Y.; Yeap Foo, L. Polyphenolics of Salvia-A review. Phytochemistry 2002, 59, 117-140.

15. Kintzios, S.E. Sage: The Genus Salvia; Harwood Academic Publishers: Amsterdam, NY, USA, 2002. 
16. Wang, M.; Li, J.; Rangarajan, M.; Shao, Y.; La Voie, E.J.; Huang, T.C.; Ho, C.T. Antioxidative phenolic compounds from sage (Salvia officinalis). J. Agric. Food Chem. 1998, 46, 4869-4873.

17. Li, L.N.; Tan, R.; Chen, W.M. Salvianolic Acid A, a New Depside from Roots of Salvia miltiorrhiza. Planta Med. 1984, 50, 227-228.

18. Ai, C.B.; Li, L.N. Stereostructure of salvianolic acid B and isolation of salvianolic acid C from Salvia miltiorrhiza. J. Nat. Prod. 1988, 51, 145-149.

19. Lin, Y.L.: Chang, Y.Y.; Kuo, Y.H.; Liu, Y.H.; Shiao, M.S. Anti-Lipid Peroxidative Principles from Tournefortia sarmentosa. J. Nat. Prod. 2002, 65, 745-747.

20. Liu, Y.; Zhang, J.T. Hydroxyl radical scavenging effect of salvianolic acids. J. Chin. Pharm. Sci. 1994, 3, 43-50.

21. Li, D.Y.; Xu, L.N.; Liu, X.G. Effects of water-soluble components isolated from Salvia miltiorrhiza on oxygen free radical generation and lipid peroxidation. J. Chin. Pharm. Sci. 1995, 4, 107-112.

22. Zhang, Y.; Akao, T.; Nakamura, N.; Duan, C.L.; Hattori, M.; Yang, X.W.; Liu, J.X. Extremely Low Bioavailability of Magnesium Lithospermate B, An Active Component from Salvia miltiorrhiza, in Rat. Planta Med. 2004, 70, 138-142.

23. Zhang, Y.; Akao, T.; Nakamura, N.; Hattori, M.; Yang, X.W.; Duan, C.L.; Liu, J.X. Magnesium lithospermate $\mathrm{B}$ is excreted rapidly into rat bile mostly as methylated metabolites, which are potent antioxidants. Drug Metab. Dispos. 2004, 32, 52-57.

24. Zhang, X.; Song, Z.; Xu, J.; Ma, Z. Improving the NQO1-Inducing Activities of Phenolic Acids from Radix Salvia miltiorrhiza: A Methylation Strategy. Chem. Biol. Drug Des. 2011, 78, 558-566.

25. Alford, B.L.; Hügel, H.M. Total synthesis of (+)-pentamethylsalvianolic acid C. Org. Biomol. Chem. 2013, 11, 2724-2727.

26. Visioli, F.: Poli, A.; Gall, C. Antioxidant and Other Biological Activities of Phenols from Olives and Olive Oil. Med. Res. Rev. 2002, 22, 65-75.

27. Foti, M.C. Antioxidant Properies of Phenols. J. Pharm. Pharmacol. 2007, 59, 1673-1685.

28. Roy, K.; Mitra, I. Advances in quantitative structure-activity relationship models of antioxidants. Exp. Opin. Drug Discov. 2009, 4, 1157-1175.

29. Razzaghi-Asl, N.; Garrido, J.; Khazraei, H.; Borges, F.; Firuzi, O. Antioxidant Properties of Hydroxycinnamic Acids: A Review of Structure-Activity Relationships. Curr. Med. Chem. 2013, 20, 4436-4450.

30. Menezes, J.C.; Kamat, S.P.; Cavaleiro, J.A.; Gaspar, A.; Garrido, J.; Borges, F. Synthesis and antioxidant activity of long chain alkyl hydroxycinnamates. Eur. J. Med. Chem. 2011, 46, 773-777.

31. Roleira, F.M.; Siquet, C.; Orru, E.; Garrido, E.M.; Garrido, J.; Milhazes, N.; Podda, G.; Paiva-Martins, F.; Reis, S.; Carvalho, R.A.; et al. Lipophilic phenolic antioxidants: Correlation between antioxidant profile, partition coefficients and redox properties. Bioorg. Med. Chem. 2010, $18,5816-5825$.

32. Garrido, J.; Gaspar, A.; Garrido, E.M.; Miri, R.; Tavakkoli, M.; Pourali, S.; Saso, L.; Borges, F.; Firuzi, O. Alkyl esters of hydroxycinnamic acids with improved antioxidant activity and lipophilicity protect PC12 cells against oxidative stress. Biochimie 2012, 94, 961-967.

33. Dawood, K.M. Benzofuran derivatives: A patent Review. Exp. Opin. Ther. Pat. 2013, 23, $133-156$. 
34. Shen, S.D.; Zhang, G.P.; Leib, M.; Hu, LH. First total synthesis of salvianolic acid C, tournefolic acid A, and tournefolal. ARKIVOC 2011, 6, 204-213.

35. Motoki, I.; Ryosuke, R.; Janagiraman, N.; Hitomi, M.; Koji, T.; Hisanori, N.; Shunichi, H. Asymmetric Total Synthesis of (-)-trans-Blechnic Acid via Rhodium(II)-Catalyzed C-H Insertion and Palladium(II)-Catalyzed C-H Olefination Reactions. Synlett 2014, 25, 288-292.

36. Kwiecien, H.; Smist, M.; Kowalewska, M. Recent Development on the Synthesis of Benzo[b]- and Naphtho[b]furans: A Review. Curr. Org. Synth. 2012, 9, 529-560.

37. De Luca, L.; Nieddu, G.; Porcheddu, A.; Giacomelli, G. Some Recent Approaches to the Synthesis of 2-Substituted Benzofurans. Curr. Med. Chem. 2009, 16, 1-20.

38. Ivanov, A.V.; Svinareva, P.A.; Tomilova, L.G.; Zefirov, N.S. Synthesis of 4,5-dihydroxyphthalonitrile. Russ. Chem. Bull. 2001, 50, 919-920.

39. Mitchell, R.H.; Lai, Y.H.; Williams, R.V. N-Bromosuccinimide-dimethylformamide: A mild, selective nuclear monobromination reagent for reactive aromatic compounds. J. Org. Chem. 1979, $44,4733-4735$.

40. Zysman-Colman, E.; Arias, K.; Siegel, J.S. Synthesis of arylbromides from arenes and N-bromosuccinimide (NBS) in acetonitrile-A convenient method for aromatic bromination. Can. J. Chem. 2009, 87, 440-447.

41. Sonogashira, K. Palladium-Catalyzed Alkynylation. In Handbook of Organopalladium Chemistry for Organic Synthesis; Negishi, E.I., Ed.; Wiley: New York, NY, USA, 2002; pp. 493-529.

42. Bernini, R., Cacchi, S.; Fabrizi, G.; Filisti, E. 2-Arylhydroxytyrosol Derivatives via Suzuki-Miyaura Cross-Coupling. Org. Lett. 2008, 10, 3457-3460.

43. Thorand, S.; Krause, N. Improved Procedures for the Palladium-Catalyzed Coupling of terminal Alkynes with Aryl Bromides (Sonogashira Coupling). J. Org. Chem. 1998, 63, 8551-8553.

44. Jung, K.Y.; Vanommeslaeghe, K.; Lanning, M.E.; Yap, J.L.; Gordon, C.; Wilder, P.T.; MacKerrell, A.D.; Fletcher, S. Amphipathic $\alpha$-Helix Mimetics Based on a 1,2-Diphenylacetylene Scaffold. Org. Lett. 2013, 15, 3234-3237.

Sample Availability: Not available.

(C) 2015 by the authors; licensee MDPI, Basel, Switzerland. This article is an open access article distributed under the terms and conditions of the Creative Commons Attribution license (http://creativecommons.org/licenses/by/4.0/). 